\title{
MAKNA SIMBOLIK DEWA NINI SEBAGAI BENTUK SAKRALISASI BUDAYA AGRIKULTUR MASYARAKAT HINDU BALI
}

\section{Putu Sabda Jayendra Komang Puteri Yadnya Diari}

\section{Ringkasan}

Pola kehidupan agrikultur pada dasarnya merupakan tonggak awal komunitas manusia dikatakan sudah mulai memiliki kebudayaan. Dengan kata lain, antara pertanian dan kebudayaan memiliki ikatan hubungan yang sangat erat. Jika ditinjau dari asal katanya, budaya menurut Soekamto (dalam Maryamah, 2016: 88) berasal dari bahasa Sansekerta buddhayah yang merupakan bentuk jamak kata buddhi yang berarti akal. Dengan demikian budaya dapat di artikan sebagai hal-hal yang berhubungan dengan akal dan budi. Dalam bahasa Inggris, kebudayaan disebut culture, yang berasal dari kata Latin colere, yaitu mengolah atau mengerjakan. Bisa diartikan juga sebagai mengolah tanah atau bertani. Kata culture juga kadang diterjemahkan sebagai "kultur" dalam bahasa Indonesia (Devianty, 2017: 230). Dengan demikian jika merujuk pada pengertian tersebut, dapat dikatakan saat manusia sudah mulai mampu "memanipulasi" alam lingkungannya dengan mengolah tanah dan bercocok tanam, barulah dikatakan memiliki kultur. Hal ini mengingat sebelum adanya pola bercocok tanam, manusia memenuhi kebutuhan makanannya dengan berburu dan mengumpulkan yang tersedia langsung di alam (hunting and food gathering). 


\section{Budaya pertanian}

Karena pentingnya pertanian sebagai penopang hidup suatu komunitas manusia, maka budaya pertanian mendapatkan prioritas utama untuk mengalami sakralisasi. Tidak terkecuali dalam kehidupan sosio-kultural masyarakat Hindu di Bali. Pertanian sangat identik dengan organisasi sosial adat istiadat yang disebut Subak. Subak merupakan organisasi sosial yang bersifat sosio-religius, karena tidak saja bertujuan dalam urusan mengatur pembagian air untuk persawahan, namun juga erat kaitannya dengan pemujaan pada Dewi Sri. Dewi Sri atau disebut juga Bhattari Sri, salah satu aspek manifestasi Ida Sang Hyang Widhi Wasa sebagai dewi kemakmuran.

Dewi Sri dalam religiusitas masyarakat Bali disthanakan di Pura Subak atau disebut pula sebagai Pura Ulun Suwi. Mayoritas upacara yang berbasis pertanian dipusatkan di pura ini. Dapat dikatakan bahwa aspek pertanian telah mendapatkan posisi yang terhormat secara sosial dan religius dalam kehidupan masyarakat Bali. Prioritas tersebut seolah ditegaskan pula dalam sifat upacaranya yang disebut tan keni antuk kapiambeng, yang maknanya tidak ada jenis kecuntakaan atau kesebelan apapun yang bisa menghentikan upacara yang berbasis pertanian. Hal ini berbeda dengan jenis upacara lainnya, dimana apabila di desa ada situasi kematian, maka upacara yang berbasis Desa Adat atau Desa Pakraman akan dihentikan sementara sampai batas waktu yang disepakati. Karakteristik inilah yang juga membuat eksistensi organisasi Subak memiliki otonomi khusus, tidak dapat diintervensi oleh Desa Adat.

Konsep kemakmuran dalam masyarakat berpola agrikultur diidentikkan dengan keberlimpahan panen beras. Oleh sebab itu, 
Dewi Sri sebagai dewi kemakmuran yang bersthana di areal Pura Subak dibuatkan palinggih berupa jineng atau lumbung padi. Bentuknya yang khas inilah yang menyebabkan Pura Subak tampak ikonik sebagaimana dapat dilihat pada gambar berikut.

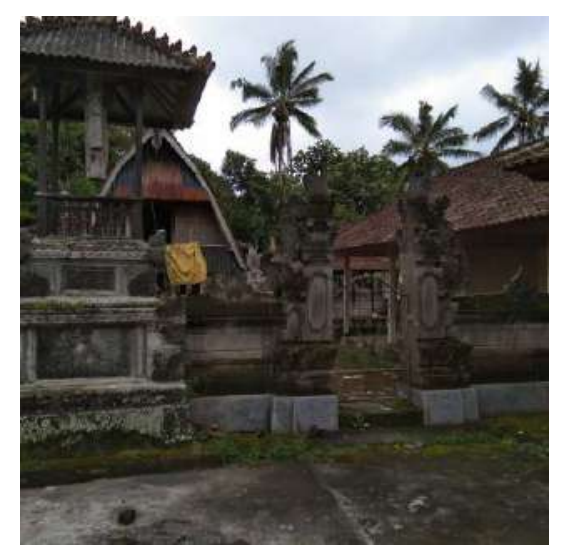

Gambar 1. Pura Subak dengan Palinggih Jineng-nya yang Ikonik (Sumber: Dokumentasi 2020).

Besarnya bentuk penghormatan masyarakat Hindu Bali terhadap budaya pertanian sebagai dewinya pertanian juga diwujudkan dengan simbolisasi berupa Dewa Nini. Dewa Nini merupakan pralingga atau simbolisasi Dewi Sri dari tanaman padi yang telah berisi bulir-bulir beras dan siap untuk dipanen. Dalam hal ini Dewa Nini merupakan bentuk sakralisasi terhadap budaya agrikultur masyarakat Bali, terutama penghormatan yang sangat tinggi terhadap tanaman padi sebagai pangan pokok.

Sektor pertanian turut mengalami pukulan yang cukup berat akibat pandemi Covid-19 yang melanda masyarakat global. Sektor pariwisata yang mengalami pukulan paling berat ternyata 
berimbas pula pada sektor lainnya, salah satunya adalah pertanian. Sektor industri perhotelan dan restaurant yang selama ini bersinergi dengan para petani sebagai supplier di Bali membuat produk-produk pertanian terserap secara maksimal. Data tahun 2017 menerangkan bahwa untuk kota Denpasar saja kebutuhan hotel berbintang dominan dipenuhi dari hasil pertanian lokal, dan sedang berada pada puncak permintaan tertinggi. Adapun persentase produk lokal yang dibutuhkan, seperti beras $(87,5 \%)$, buah $(80 \%)$, sayur $(90 \%)$, daging $(50 \%)$, telur $(100 \%)$, bumbu (100\%), dan bunga (90\%) (Pertiwi dkk, 2017: 27). Namun pada masa pandemi yang menyebabkan banyak hotel dan restaurant tidak beroperasi, maka permintaan terhadap produk pertanian berkurang sangat drastis. Namun di masa sulit tersebut, sakralisasi budaya pertanian turut andil dalam menjaga kebertahanan sektor pertanian di Bali. Terutama melalui simbolisasi Dewa Nini yang jelas merujuk pada sakralisasi tanaman padi sebagai simbol Dewi Sri yang menjadi simbol kemakmuran.

\section{Deskripsi dan Ritual Dewa Nini}

Ritual yang menyangkut Dewa Nini sesungguhnya merupakan bagian dari rangkaian upacara yang berbasis Subak. Upacara-upacara tersebut menjadi satu kesatuan rangkaian seiring dengan perjalanan tumbuh kembang tanaman padi. Dewa Nini pertama kali dibuat simbolisasinya pada saat Upacara Ngadegang Dewa Nini. Momentum pelaksanaannya dilakukan dengan melihat apabila padi sudah mulai menguning dan bulir-bulir buah padinya telah panjang dan lebat.

Dewa Nini dibuat dari batang padi yang telah berisi bulirbulir padi yang sehat, tidak rusak atau cacat serta dalam istilah 
Bali disebut jelih dan lambih, yang artinya berisi bulir padi yang padat dan panjang. Batang-batang padi yang dipilih lalu diikat dengan tali bambu, dihiasi dengan bunga dan janur, layaknya seperti manusia laki dan perempuan, sebagaimana tampak dalam gambar berikut.

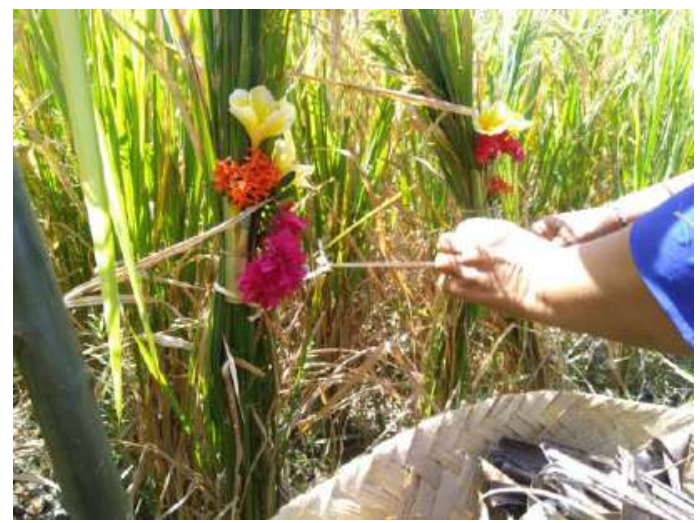

Gambar 2. Pembuatan Dewa Nini dari Tanaman Padi (Sumber: Dokumentasi 2020).

Selanjutnya Dewa Nini tersebut dipotong pangkalnya dengan menggunakan anggapan (anai-anai) dan Padi yang diikat dan dijadikan Dewa Nini disimbolkan dengan aspek kelaki-lakian (lanang) dan aspek kewanitaan (wadon). Simbol lanang disebut juga Kaki Manuh dan simbol wadon-nya disebut juga Nini Manuh. Jumlah batang padi berbeda untuk lanang dan wadon. Untuk ikatan padi yang diperuntukkan sebagai simbol lanang, jumlahnya 108 (seratus delapan) batang ikatan, sedangkan ikatan padi yang diperuntukkan sebagai simbol wadon jumlahnya sebanyak 54 (lima puluh empat) batang ikatan.

Dewa Nini tersebut lalu dijejerkan secara tegak (ngadegang) pada Palinggih Pangulun Carik. Disanalah para 
Krama Subak melakukan persembahyangan. Tujuannya adalah untuk mengungkapkan rasa syukur atas keberhasilan tanaman padi dalam menghasilkan bulir-bulir biji padi yang siap untuk dipanen. Selanjutnya diadakanlah Upacara Mantenin di Lumbung, dimana Dewa Nini kemudian di sthanakan di Lumbung atau Jineng. Menurut kepercayaan petani, padi itu baru boleh diturunkan dari lumbung untuk ditumbuk ataupun dibawa ke tempat penggilingan beras setelah dilaksanakan ritual mantenin (Aridawati, 2020: 400). Tujuannya utama dari upacara ini sendiri secara keseluruhan adalah agar Dewi Sri berkenan untuk senantiasa bersthana dalam setiap tanaman padi, memberi kemakmuran, serta terhindar dari hama.

\section{Makna Simbolik Dewa Nini dalam Budaya Agrikultur}

Hakikat Ida Sang Hyang Widhi Wasa (Tuhan Yang Maha Esa) adalah acintyarupa, tidak berwujud, tidak berkepribadian, dan termasuk juga tidak berjenis kelamin. Dalam istilah Sanskrta, Tuhan disebut neti-neti, yang artinya bukan ini dan bukan itu, yang secara simbolik merujuk pada sifat Tuhan yang tidak berpribadi dan tidak dipersonifikasikan.

Masyarakat cenderung mempersonifikasikan Tuhan dalam aspek maskulin dengan manifestasi dewa-dewa. Namun simbol Dewa Nini dalam hal ini mencerminkan dominasi aspek feminisme. Dewa Nini sendiri merupakan simbol dari Dewi Sri sebagai dewinya padi atau pertanian, namun dibedakan pula dalam dua kategori unsur, yaitu Kaki Manuh sebagai simbol purusa dan Nini Manuh sebagai simbol pradhana. Ini berarti Dewi Sri sebagai personifikasi Tuhan yang feminim berada di atas kedua unsur tersebut. 
Padi merupakan benih sumber kehidupan yang berasal dari pertemuan purusa dan pradhana. Sumber kehidupan yang ajeg itu disimbolkan dengan urip tertinggi dalam agama Hindu, yaitu angka 9. Angka 9 diperoleh dari jumlah Dewa Nini lanang dan wadon yang berjumlah 108 dan 54 tersebut. Oleh sebab itu, maka makna dari angka 108 yaitu angka 1 (satu) bila ditambah dengan angka 8 (delapan) berarti hasilnya angka 9 (sembilan) yang melambangkan Pengider Bhuwana (Dewata Nawa Sanga) sedangkan angka 0 (nol) disimbolkan dengan Windu atau dunia. Dengan kata lain 108 dapat diartikan sebagai persembahan kepada Dewata Nawa Sanga yang mengelilingi dunia (Suardi dkk, 2018: 445, Sarjana, 2020: 147). Begitupula angka 54 apabila digabungkan antara angka 5 (lima) ditambah dengan 4 (empat) maka akan berjumlah 9 (sembilan). Beranjak dari konsep tersebut, maka simbolisasi Dewa Nini bertujuan untuk mengungkapkan rasa terima kasih atas tercapainya keseimbangan kehidupan alam yang terbentuk dari permulaan, yakni unsur purusa dan pradhana.

Aspek feminisme dalam budaya agrikultur masyarakat Hindu Bali juga diperkuat dengan adanya pernyataan dalam lontar Aji Pari, dimana leksikon kata nini diulas dengan sangat jelas. Dalam teks tersebut, padi memiliki gelar sebagai "nini tohok" atau "nini towok". Istilah nini juga bermakna wanita tua atau wanita yang dihormati (setara nenek). Gelar mulia padi sangat erat kaitannya dengan manifestasi Yang Maha Kuasa sebagai wujud kekuatan feminis. Dalam proses pemanenan pun yang lebih dominan bekerja adalah para wanita. Selain itu, wanita dipercaya sebagai simbol kesejahteraan keluarga di dalam sistem kepercayaan dan kebudayaan Bali (Diari, 2020: 82). 


\section{2 | Book Chapter}

Dominasi aspek feminisme dalam budaya agrikultur yang dipersonifikasikan dengan Dewi Sri ini juga akhirnya menginfiltrasi seluruh jenis upacara yadnya yang dilaksanakan oleh masyarakat Hindu Bali. Hal ini dibuktikan dengan adanya penggunaan bija, yaitu beras yang ditempelkan di kening, pangkal lengan, dan ditelan pada saat umat Hindu selesai melaksanakan persembahyangan.

Bija merupakan lambang Dewi Sri dan digunakan sebagai simbol anugerah kemakmuran yang diperoleh sehabis melaksanakan persembahyangan. Hal ini dimaklumi mengingat bahwa dalam budaya agrikultur, keberlimpahan beras merupakan indikator utama bagi kemakmuran. Penempatan bija di kening, pangkal tenggorokan dan lengan (atas dada), dan yang ditelan tiga biji tanpa dikunyah tersebut juga memuat filosofi yang sangat dalam. Penempatan di kening memiliki makna penyucian pikiran (manacika), ditelan tiga biji tanpa dikunyah memiliki makna penyucian ucapan di lidah (wacika), serta di pangkal lengan dan tenggorokan memiliki makna pengendalian perbuatan (kayika). Dengan demikian diharapkan manusia senantiasa menanamkan sifat-sifat kedewataan agar tercipta kemakmuran dan kesejahteraan bersama.

Filosofi lainnya terkait dengan penempatan bija tersebut adalah dari segi letaknya yang merepresentasikan simbol tapak dara (+), baik di kening, pangkal tenggorokan dan lengan, serta yang ditelan masuk ke perut sebagai pusat bhuwana alit atau tubuh manusia. Titik-titik centrum tersebut melambangkan pertemuan purusa dan pradhana (garis vertikal), serta keseimbangan hidup dengan sesama makhluk (garis horizontal) (Jayendra, 2016: 86-87). Pertemuan dan keseimbangan tersebut 
akan menghasilkan kemakmuran yang disimbolkan dengan bija atau beras.

Hal ini seolah menegaskan esensi budaya agrikultur telah menjadi bagian yang tidak terpisahkan dari kehidupan sosio kultural masyarakat Hindu Bali. Simbolisasi Dewi Sri dalam bentuk Dewa Nini menjadi representasi dari aspek feminis Tuhan yang memiliki fungsi sentral secara spiritual dalam menjaga keberlangsungan budaya agrikultur di Bali, dan artinya secara tidak langsung turut berpengaruh terhadap eksistensi ritual yadnya yang lainnya. Dengan demikian, kebertahanan budaya agrikultur tidak saja berimplikasi terhadap kehidupan sosial, namun juga secara religius.

Sakralisasi budaya agrikultur di Bali memiliki implikasi yang sangat kuat bagi masyarakat, terutama di masa pandemi Covid-19 seperti saat ini. Masyarakat di satu sisi merasa wajib melestarikan tradisi warisan leluhur. Jika budaya pertanian ditinggalkan, maka otomatis tidak ada upacara yang dilangsungkan. Jika upacara tidak dilangsungkan, maka dianggap akan tulah atau ingkar terhadap ajaran leluhur. Oleh sebab itu jalan satu-satunya adalah budaya pertanian harus tetap dijamin kebertahanannya.

\section{Daftar Pustaka}

Aridawati, I.A.P., 2020. Makna Ritual Budaya Pertanian Yang Berkaitan Dengan Leksikon Bidang Persawahan Pada Masyarakat Bali. Kamaya: Jurnal Ilmu Agama, 3(3), pp.384-402.

Devianty, R., 2017. Bahasa sebagai cermin kebudayaan. Jurnal Tarbiyah, 24(2). 
Diari, Komang Puteri Yadnya. 2020. Aspek Eko-Religius dalam Naskah Lontar Pertanian di Bali. Singaraja: Penelitian Dosen Pemula Sekolah Tinggi Agama Hindu Negeri Mpu Kuturan.

Jayendra, P.S., 2018. Filosofi Penggunaan Bija Dalam Persembahyangan Umat Hindu Di Bali. Jurnal Brahma Widya, 3(2).

Maryamah, E., 2016. Pengembangan Budaya Sekolah. Tarbawi: Jurnal Keilmuan Manajemen Pendidikan, 2(02), pp.86-96.

Pertiwi, P.R., Widyatmaja, I.G. and Ariana, N.J., Optimalisasi Pola Pemanfaatan Produk Pertanian Lokal Dalam Memenuhi Kebutuhan Hotel Berbintang Di Kota Denpasar. Jurnal Analisis Pariwisata, 17(1), pp.24-30.

Sarjana, I Wayan Mula. 2020. Upacara Ngusaba Majelih Lambih di Subak Perean Desa Perean Kecamatan Baturiti Kabupaten Tabanan: Kajian Sosioreligius Hindu. Denpasar: Disertasi Program Pascasarjana Institut Hindu Dharma Negeri.

Suardi, P., Redi, I.W. and Piartha, I.N., 2018. Makna Teologi Upakara Nasi Gede Lanang Istri Dalam Rangkaian Hari Raya Nyepi Di Desa Kalisada Kecamatan Seririt Kabupaten Buleleng. Jurnal Penelitian Agama Hindu, 2(1), pp.444-450. 